\title{
Occurrence of Braga cigarra (Cymothoidae) parasitizing Galeocharax knerii (Characidae) from affluents of Jurumirim reservoir, Brazil
}

\author{
Ocorrência de Braga cigarra (Cymothoidae) parasitando Galeocharax knerii (Characidae) \\ de afluentes da represa de Jurumirim, Brasil \\ Heleno Brandão ${ }^{1 *}$; Gislayne de Melo Toledo ${ }^{1}$; Alison Carlos Wunderlich ${ }^{1}$; \\ Igor Paiva Ramos ${ }^{1}$; Edmir Daniel Carvalho ${ }^{2}$; Reinaldo Jose da Silva ${ }^{1}$
}

\begin{abstract}
${ }^{1}$ Department of Parasitology, College of Biosciences, Universidade Estadual Paulista - UNESP, Botucatu, SP, Brazil
${ }^{2}$ Department of Morfology, College of Biosciences, Universidade Estadual Paulista - UNESP, Botucatu, SP, Brazil
\end{abstract}

Received May 24, 2012

Accepted June 25, 2012

\begin{abstract}
The occurrence of the cymothoidae Braga cigarra is reported parasitizing the oral cavity of freshwater fish Galeocharax knerii from Veados, Paranapanema and Taquari Rivers, affluent of the Jurumirim Reservoir, State of Sao Paulo, Brazil is reported. The isopod species were identified based on the multilaminar pleopods, narrow pleon and short pleotelson in females. The overall prevalences of isopods were $31.7 \%, 7.7 \%$ and $5.7 \%$, respectively, in the Paranapanema, Veados and Taquari Rivers. This note contributes to the knowledge of the geographical distribution and fauna of parasite crustaceans known to date in these important ecosystems.
\end{abstract}

Keywords: Freshwater rivers, crustacean parasite, teleost fish, Braga cigarra, Galeocharax knerii.

\section{Resumo}

Foi registrada a ocorrência do cymothoidae Braga cigarra parasitando a cavidade bucal do peixe de água doce Galeocharax knerii capturado nos rios Veados, Paranapanema e Taquari, afluentes da represa de Jurumirim, Estado de São Paulo, Brasil. As espécies de isópodas foram identificadas com base nos pleópodos multilaminares, abdômen estreito e pleotelson curto nas fêmeas. As prevalências totais de isópodos foram 31,7\%, 7,7\% e 5,7\%, respectivamente, nos rios Paranapanema, Veados e Taquari. Essa nota contribui com o conhecimento da distribuição geográfica e da fauna de crustáceos parasitas conhecidas até a presente data nesses importantes ecossistemas aquáticos.

Palavras-chave: Rios de água doce, crustáceo parasita, peixe teleósteo, Braga cigarra, Galeocharax knerii.

Brazil has the largest hydrographic network in the world and ranks among the most important countries in terms of freshwater fish diversity (GRAÇA; PAVANELLI, 2007). However, little is known regarding the diversity of neotropical fish parasites (EIRAS et al., 2010).

The study of fish parasites provides important information about their hosts and environment. Fish present a greater number and variety of parasites than any other class of vertebrates, because these organisms have experienced a long period of time in close association with a variety of invertebrate forms with the major parasite groups of neotropical freshwater: Protozoa, Myxozoa, Cestoda, Nematoda, Acanthocephala, arthropods (Copepoda,

*Corresponding author: Heleno Brandão

Departamento de Parasitologia, Instituto de Biociências, Universidade Estadual Paulista - UNESP, CEP 18618-970, Botucatu, SP, Brasil

e-mail: heleno_brandao@hotmail.com
Brachyura and Isopoda), Annelida (Hirudinea) and Pentastomida (THATCHER, 2006).

The species of the family Cymothoidae are dorse-ventrally flattened isopod crustaceans found in marine, brackish and freshwater environments (TRILLES, 1994). Most of the fish parasitic isopods are included in the family Cymothoidae (THATCHER, 2006). These isopods are generally found on the body surface, inside gill chambers, oral cavity and may lodge in down scales, forming a cavity in the body (PAVANELLI et al., 1999; LIMA et al., 2005). Probably all the species of Cymothoidae are protandric hermaphrodites, which penetrate the hosts as males and later originate the females in the gills or mouth (EIRAS, 1994). South America has the greatest variety of freshwater cymothoids of the world. At least twenty-seven species and nine genera have been recorded in South America (THATCHER, 2006).

The freshwater fish Galeocharax knerii, popularly known as "peixe cadela" in Brazil, is a medium-sized species distributed in 
rivers and lakes in the Neotropical region, especially in the upper Parana River basin (REIS et al., 2003).

The occurrence of Braga cigarra (THATCHER et al., 2009) was reported herein, in the oral cavity of $G$. knerii captured in the main tributary of Jurumirim Reservoir, upper Parana River basin, State of Sao Paulo, Brazil.

The Jurumirim dam is the first reservoir in cascade on the Paranapanema River and operates as a reservoir for regulating others further downstream. The reservoir is located between the coordinates $23^{\circ} 12^{\prime} 17^{\prime \prime} \mathrm{S}$ and $49^{\circ} 13^{\prime} 19^{\prime}$ 'W. It was built in the late 1950s and began operating in 1962 (HENRY; NOGUEIRA, 1999).

Fish were collected from April 2011 to January 2012 in the following tributaries of Jurumirim Reservoir: Veados River, municipality of Itatinga, State of Sao Paulo, Brazil, 23 15' 42.4” S and $48^{\circ} 37^{\prime} 27.6^{\prime \prime} \mathrm{W}$; Paranapanema River, municipality of Angatuba, State of Sao Paulo State, Brazil, 23 12' 17' S and 49 13'19” W; and Taquari River, municipality of Taquarituba, State of Sao Paulo, Brazil, 23 15' 11.9” S and 49 12'34.2” W (Figure 1). The parasites were removed from the oral cavity of the hosts with the aid of forceps and transferred to flasks containing $10 \%$ formalin; after 24 hours, they were transferred to alcohol $70 \%$. Adult females were known to show a marsupium on the ventral surface. The marsupial cavity was carefully dried to verify the presence of eggs.

In the laboratory, the isopods $B$. cigarra (Figure 2) were identified according to Thatcher et al. (2009). The images were obtained using a computerized image analysis system (LAS, Leica Microsystems, Wetzlar, Germany). Representative specimens of B. cigarra were deposited in the Helminthological Collection of the College of Biosciences (CHIBB), at "Universidade Estadual Paulista” - UNESP, Botucatu, State of Sao Paulo, Brazil.

The following amounts of specimens of $G$. knerii were examined: 190 from Paranapanema River, 23 from Veados River, and 17 from Taquari River. Six cymothoids were found in the oral cavity

Table 1. Mean and range of standard length $\left(\mathrm{L}_{\mathrm{s}}\right)$ and weight $\left(\mathrm{W}_{\mathrm{t}}\right)$ of Galeocharax knerii from Veados, Paranapanema and Taquari rivers, Jurumirim Reservoir, State of Sao Paulo, Brazil.

\begin{tabular}{llc}
\hline \multicolumn{1}{c}{ Rivers } & \multicolumn{1}{c}{$\mathbf{L}_{\mathbf{s}} \mathbf{c m}$} & $\mathbf{W}_{\mathbf{t}} \mathbf{g}$ \\
\hline Veados & $13.5(21.3-8.9)$ & $44.3(164.4-9.4)$ \\
Paranapanema & $18.8(25.6-8.2)$ & $97.8(254.6-8.47)$ \\
Taquari & $19.4(24.1-11.1)$ & $156.9(248.2-20.2)$ \\
\hline
\end{tabular}

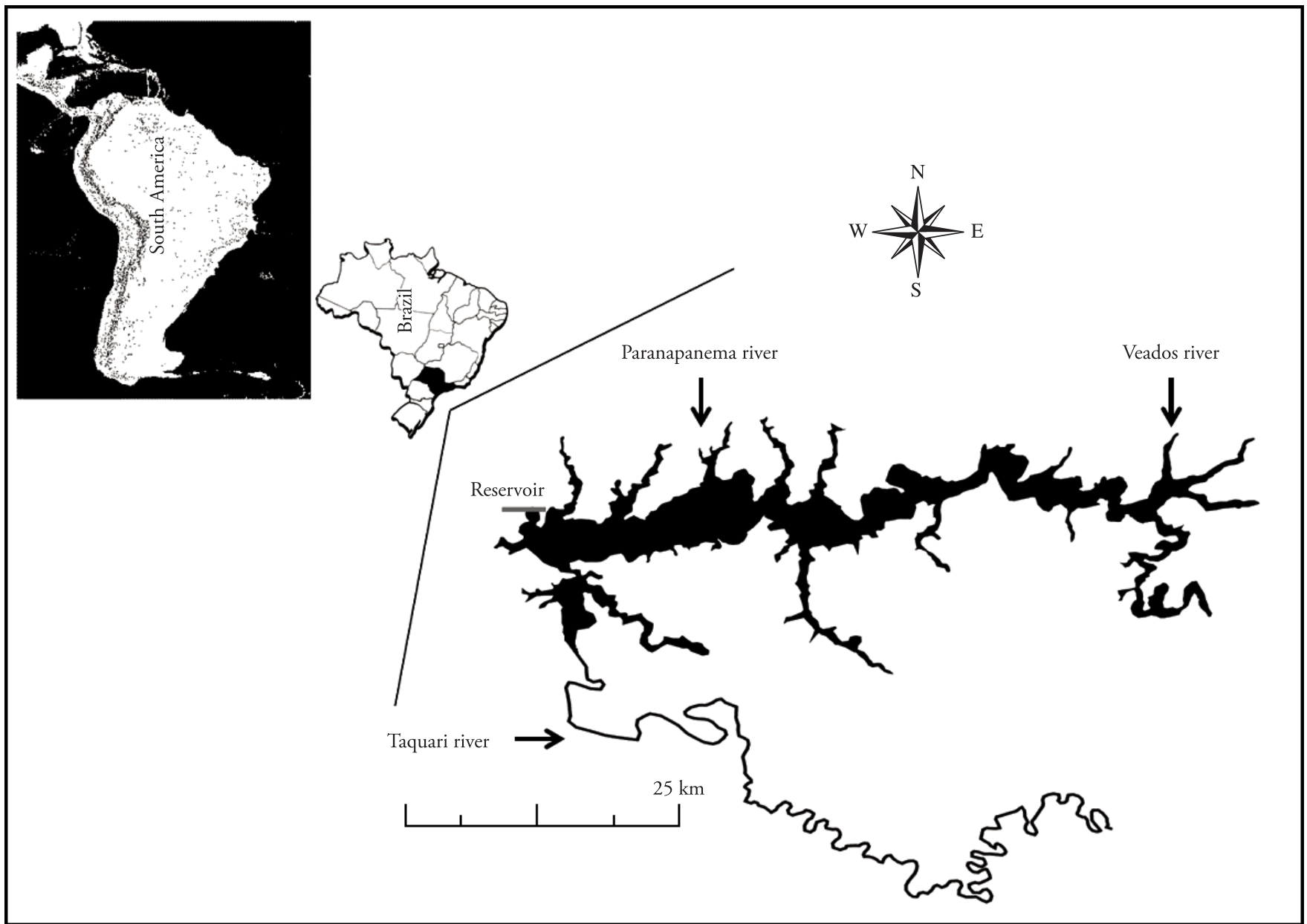

Figure 1. Location of affluent of the Jurumirim reservoir, State of Sao Paulo, Brazil; sampling rivers indicated by arrows (Source: modified from GoogleEarth - DigitalGlobe). 
of the host caught from Veados River and three in each one from Paranapanema and Taquari rivers (Table 1). Only one species was found in the oral cavity of each host. The body length and width of each isopod were taken in dorsal view, using a caliper (Table 2).

There are few studies on the prevalence of isopod species in nature. Szidat and Schubart (1960) observed a prevalence of $90 \%$ of B. cigarra (=Philostomella cigarra), in "peixe cadela" (G. knerii) from Mogi Guassu River in the region of Cachoeira de Emas in the State of Sao Paulo. In this study, it was possible to observe a higher prevalence in Paranapanema River (31.7\%), compared to Veados $(7.7 \%)$ and Taquari $(5.7 \%)$ rivers. However, it may be difficult to estimate the real prevalence of parasitic crustaceans
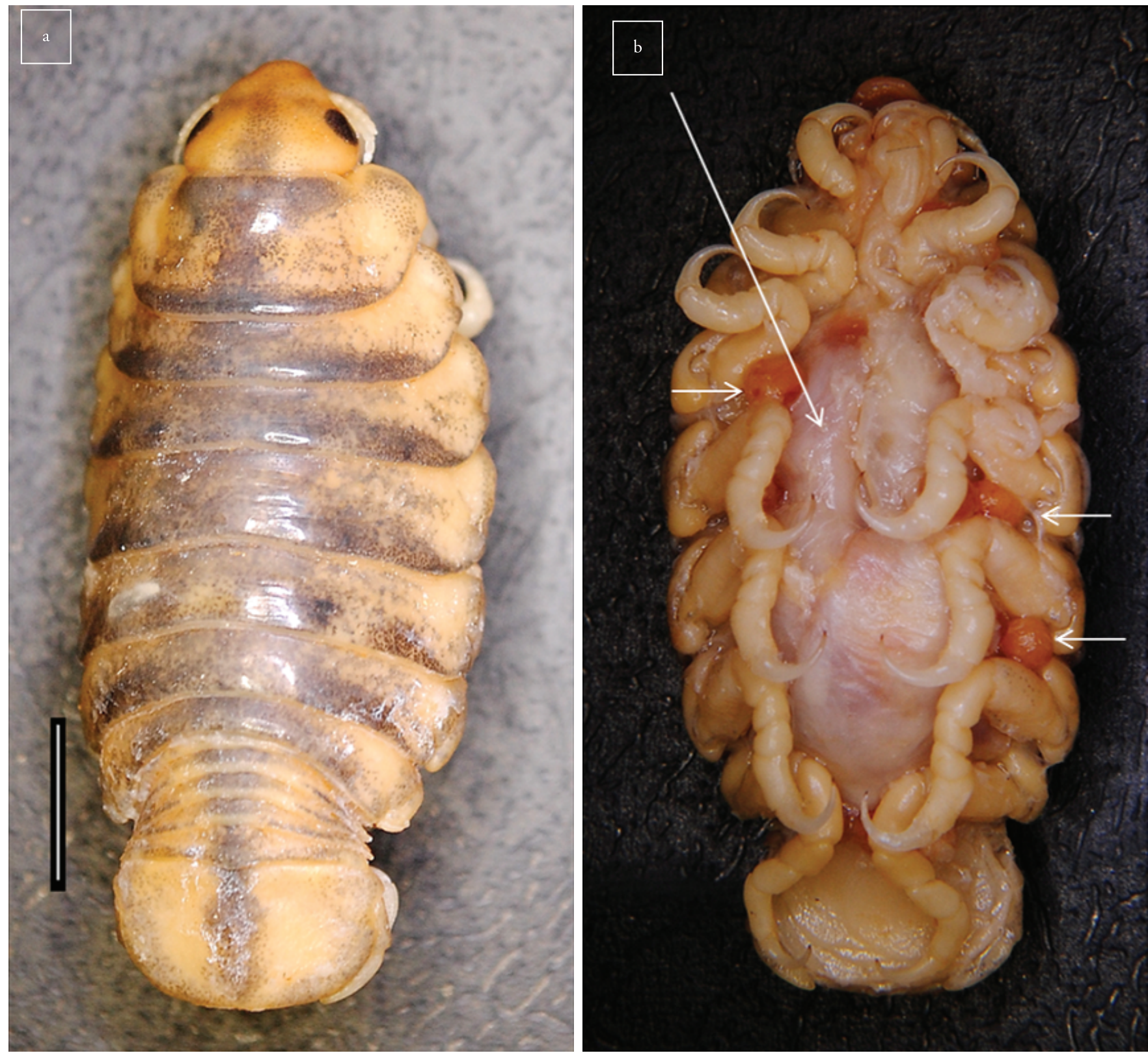

Figure 2. Braga cigarra entire dorsal a) and entire ventral, at arrow, ventral marsupium with eggs attached b). Scale bar $=2 \mathrm{~mm}$.

Table 2. Biometry of the body (in millimeters) of Braga cigarra found in the oral cavity of Galeocharax knerii from Veados, Paranapanema and Taquari rivers, Jurumirim Reservoir, State of Sao Paulo, Brazil. Values are presented as mean \pm standard deviation.

\begin{tabular}{lcccccc}
\hline \multicolumn{1}{c}{ Rivers } & \multicolumn{2}{c}{ Sex } & \multicolumn{2}{c}{ Male measurements } & \multicolumn{2}{c}{ Female measurements } \\
\cline { 2 - 7 } & Male & Female & Length & Width & Length & Width \\
\hline Veados & - & 6 & - & - & $20.9 \pm 5.1$ & $9.48 \pm 2.3$ \\
Paranapanema & 2 & 1 & $19.7 \pm 2.3$ & $9.5 \pm 1.5$ & 16.3 & 7.4 \\
Taquari & - & 3 & - & - & $22.3 \pm 0.9$ & $10.4 \pm 0.1$ \\
Total & 2 & 10 & $19.7 \pm 2.3$ & $9.5 \pm 1.5$ & $20.8 \pm 4.2$ & $9.5 \pm 1.9$ \\
\hline
\end{tabular}


in the natural environment since after they were caught by fishing nets, they try to escape with strong movements and, in the course of time, stress increases and metabolism tends to decrease, which can lead the isopod to go out of the oral cavity of the host and explore a new habitat for survival (author's personal information).

The isopod B. cigarra is characterized by Cephalon with pointed snout; head with antennula shorter than the antenna, all pereopods with claws adapted for attachment to the host; wider rather than longer pleotelson and pleon slightly immersed in pereonite; long pereopod and multilaminate pleopods. All parasites found were identified as B. cigarra (Figures 2 and 3), as re-described by Thatcher et al. (2009). Table 3 shows the records of occurrences of this species to date.

The present study reports the occurrence of $B$. cigarra parasitizing G. knerii from Veados, Paranapanema and Taquari rivers (upper Parana River basin), contributing to the knowledge of the distribution of this cymothoid in Brazil. These parasites are relatively easy to be visualized, because they are large in size and have legs equipped with strong jaws adapted to be fixed to the host. Usually, pathogenic phenomena are limited to the site of attachment, where compression of the tissue and massive infiltration of lymphocytes can be observed (PAVANELLI et al., 2008).
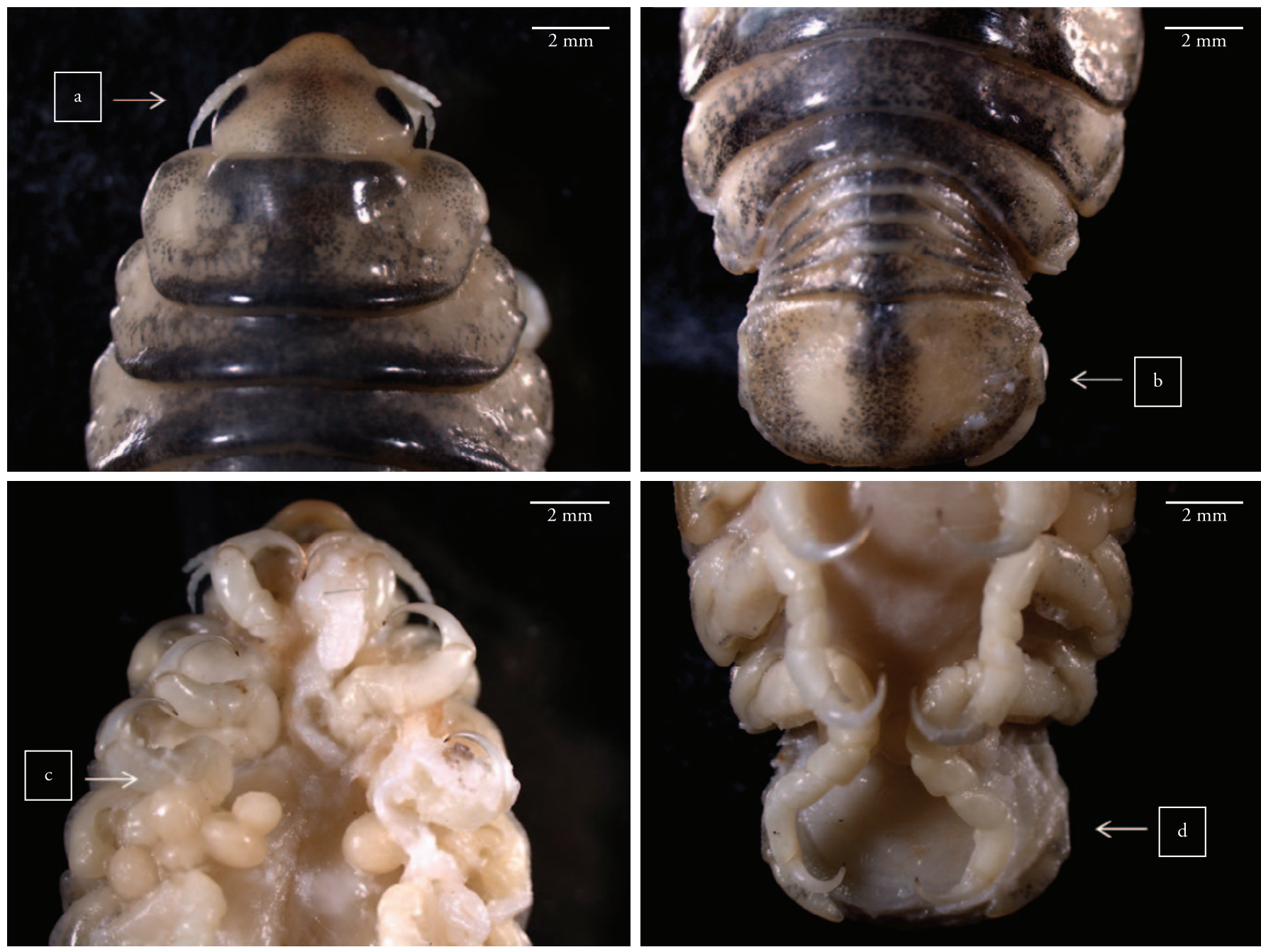

Figure 3. Braga Cigarra. External anatomical structure: a) head with pointed snout, antenna and antennule; b) pleotelson; c) pereopod and eggs adhered to the ventral; and d) multilaminate pleopods.

Table 3. Geographical distribution of Braga cigarra parasitizing the oral cavity of their hosts in South America, Brazil.

\begin{tabular}{cll}
\hline Host & \multicolumn{1}{c}{ Locality } & \multicolumn{1}{c}{ References } \\
\hline Galeocharax humeralis & Mogi-Guassú River & Szidat and Schubart (1960) \\
Galeocharax humeralis & Mogi-Guassú River & Taberner (1986) \\
Galeocharax knerii & Grande River & Thatcher et al. (2009) \\
Galeocharax knerii & Veados River & This study \\
Galeocharax knerii & Paranapanema River & This study \\
Galeocharax knerii & Taquari River & This study \\
\hline
\end{tabular}


B. cigarra is differentiated from other genera by having narrow pleon and small pleotelson in females. This species was recorded and originally described by Szidat and Schubart (1960) in the MogiGuaçu River, State of Sao Paulo, Brazil, as Philostomella cigarra in the host Galeocharax humeralis. It was later redescribed by Thatcher et al. (2009) parasitizing the mouth of G. knerii in Rio Grande river, State of Minas Gerais, Brazil.

The possible losses associated with isopods living under the tongue of fish are difficult to assess; although the tongue of the host may be reduced in size, there is no direct evidence to indicate that the tissue was eaten (THATCHER, 2006). However, in the host studied herein, apparently, there was a compression of the tongue tissue where the parasite was attached.

The knowledge on the geographical distribution of cymothoids is also of considerable importance, since these organisms can be used as tools to aid in the understanding, conservation and preservation of aquatic ecosystems. Thus, this study contributes to the knowledge of the geographical distribution of B. cigarra in Veados, Paranapanema and Taquari rivers, affluent of Jurumirim reservoir, Brazil.

\section{Acknowledgements}

The authors are grateful to the "Coordenação de Aperfeiçoamento Pessoal de Nivel Superior” - CAPES (process number AUX-PEPNPD 3005/2010) for the scholarship granted to the first author, to Drausio Honorio Morais, for his assistance with the photos, and to the "Universidade Estadual Paulista" - UNESP, Botucatu Campus, for the structure offered for the development of this work (FAPESP process: 2010/19543-6).

\section{References}

Eiras JC. Elementos de ictioparasitologia. Porto: Fundação Eng. Antônio de Almeida; 1994.

Eiras JC, Takemoto RM, Pavanelli GC. Diversidade dos parasitas de peixes de água doce do Brasil. Maringá: Clichetec; 2010.
Graça WJ, Pavanelli CS. Peixes da planície de inundação do alto rio Paraná e áreas adjacentes. Maringa: Eduem; 2007.

Henry R, Nogueira MG. A Represa de Jurumirim (São Paulo): Primeira síntese sobre o conhecimento limnológico e uma proposta preliminar de manejo ambiental. In: Henry R. Ecologia de reservatórios: estrutura, função e aspectos sociais. Botucatu: Fapesp/Fundibio; 1999. p. 651-685.

Lima JTAX, Chellappa S, Thatcher VE. Livoneca redmanni Leach (Isopoda, Cymothoidae) e Rocinela signata Schioedte \& Meinert (Isopoda, Aegidae), ectoparasitos de Scomberomorus brasiliensis Collette, Russo \& Zavala-Camin (Ostheichthyes, Scombridae) no Rio Grande do Norte, Brasil. Rev Bras Zool 2005; 22(4): 1104-1108. http://dx.doi. org/10.1590/S0101-81752005000400041

Pavanelli GC, Eiras JC, Takemoto RM. Doenças de peixes: profilaxia, diagnóstico e tratamento. Maringá: Eduem; 1999.

Pavanelli GC, Eiras JC, Takemoto RM. Doenças de peixes profilaxia, diagnóstico e tratamento. 3. ed. Maringá: Eduem; 2008.

Reis RE, Kullander SO, Ferraris Junior CJ. Check list of the freshwater fishes of South and Central America. Porto Alegre: EdiPUCRS; 2003.

Szidat L, Schubart O. Neue und seltene Parasitische Süsswasser Anselm der Familie Cymothoidae aus dem Rio Mogi-Guassú, Brasilien (Isopoda). An Acad Bras Ciênc 1960; 32(1): 107-124.

Taberner R. Redescripción y posición sistemática de Philostomella cigarra Szidat y Schubart, 1960 (Isopoda: Cymothoidae). Physis, Sección B 1986; 44(107): 95-101.

Thatcher VE. Aquatic Biodiversity in Latin America a - Amazon Fish Parasites. Pensoft Publishers; 2006.

Thatcher VE, Oliveira AAN, Garcia AM. Braga cigarra comb. nov. for Philostomella cigarra (Crustacea: Isopoda: Cymothoidae) with a redescription of the species based on specimens from Galeocharax kneri, a freshwater fish of Minas Gerais State, Brazil. Zoologia 2009; 26(1): 155-160.

Trilles JP. Les Cymothoidae (Crustacea, Isopoda) du Monde (Prodrome pour une faune). Studia Marina 1994; 21-22(1-2): 1-288. 